\title{
Supply chain management practices as a mediator of the relationship between operations capability and firm performance
}

\author{
C.-C. Hsu , K. C. Tan , V. R. Kannan \& G. Keong Leong
}

To cite this article: C.-C. Hsu , K. C. Tan , V. R. Kannan \& G. Keong Leong (2009) Supply chain management practices as a mediator of the relationship between operations capability and firm performance, International Journal of Production Research, 47:3, 835-855, DOI:

10.1080/00207540701452142

To link to this article: https://doi.org/10.1080/00207540701452142

\section{曲 Published online: 20 Nov 2008.}

\section{Submit your article to this journal $\llbracket$}

Џ Article views: 946

Citing articles: 56 View citing articles $[7$ 


\title{
Supply chain management practices as a mediator of the relationship between operations capability and firm performance
}

\author{
C.-C. HSU†, K. C. TAN*†, V. R. KANNAN† and G. KEONG LEONG $\dagger$ \\ $†$ College of Business, University of Nevada Las Vegas, 4505 Maryland Parkway, \\ Box 456009, Las Vegas, NV 89154-6009 \\ \$College of Business, Utah State University, Logan, UT 84322-3510
}

(Revision received May 2007)

\begin{abstract}
The current study uses mediated regression analysis and structural equation modelling to test the proposition that supply chain management practices mediate the relationship between operations capability and firm performance. Operations capability is defined in terms of a firm's new product design and development, total quality management and just-in-time capabilities. Results support the research model and also suggest the existence of a direct relationship between operations capability and performance.
\end{abstract}

Keywords: Operations capability; Supply chain management; Firm performance

\section{Introduction}

Supply chain management stresses the seamless integration of value-creating activities across organizational boundaries. It enables firms in a supply chain to eliminate waste, leverage synergies and compete more effectively in an intensely competitive global market. Accordingly, a strategic focus on managing the supply chain represents a top-level management initiative to integrate value-adding activities across both functional and organizational boundaries. The specific strategy adopted depends on, among other factors, industry, product type, and level of integration. However, in each case, the principle objective is to develop and implement intra and inter-organizational boundary-spanning relationships within the supply chain that enable members to integrate activities and leverage individual capabilities. Attempts by companies to implement supply chain management practices have not however been universally successful. In many cases, efforts have failed to yield positive results despite substantial resources being expended on them. This may be in part due to a lack of insight into the relationship between supply chain management practices and other elements of a firm's portfolio of operations capabilities.

The resource based view of the firm suggests that creating and preserving competitive advantage is a function of the core resources and capabilities that supply chain members provide in a given environment (Barney 1995). These represent the primary source of a firm's success (Grant 1991). Many research efforts stem from the

*Corresponding author. Email: kctan@unlv.nevada.edu 
theoretical assertion that the heterogeneity of organizational resources leads to differentiation in a firms' competitive advantage (Prahalad and Hamel 1990, Randall et al. 2003). In today's competitive market, for firms to simultaneously offer goods and services at low cost and high quality requires the integration of the operations capabilities of multiple supply chain members. To create competitive advantage, firms must develop and use their core resources to develop these capabilities in a manner that inhibits duplication by competitors (Dutta et al. 1999). Research shows that firms with similar levels of operations capability in the same market segment can have different levels of performance (Cool and Schendel 1988). Moreover, a firm's operations capability can create value both for the firm and its suppliers and customers (Porter 1980, 1985).

While operations capability at the firm level has been studied extensively (e.g., Nakane 1986, Ferdows and De Meyer 1990, Roth and Miller 1992), evidence of the impact of supply chain management practices on operations capability and firm performance is limited and inconclusive. The current research addresses this gap in the literature by analysing the roles of operations capability and supply chain management practice on firm performance. Drawing from the literature, we posit that operations capability is an enabler and antecedent of supply chain management practices, and that supply chain management practices mediate the relationship between operations capability and performance. In the following section, the conceptual model and research hypotheses are presented. In subsequent sections, the methodology, measurement, and statistical analyses, are addressed followed by discussion of the results. Finally, limitations of the study and directions for further research are provided.

\section{Theoretical background and conceptual framework}

Research in supply chain management has increasingly applied theories and conceptual contributions drawn from the strategy literature. The resource based view of the firm is a particularly appropriate theoretical framework for studying the performance implications of managing the supply chains (e.g., Olavarrieta and Ellinger 1997, Zsidisin et al. 2003, Sinkovics and Roath 2004). Grounded in evolutionary economics and the work of Penrose (1959), the resource based view complements traditional industrial organizational theory (performance is a function of industry structure and positioning) by recognizing the competitive value of resources/capabilities, and how they combine with and influence strategies pursued by a firm. Firms build competitive advantage by utilizing unique sets of resources and strategies (Wernerfelt 1984, Barney 1991). Resources are heterogeneous, and typically include all assets, capabilities, processes, and knowledge controlled by a firm. Resources enable firms to conceive and implement strategies, thereby improving their effectiveness (Barney 1991). In contrast, strategies are the means by which firms relate to their external environment (Porter 1985). They are the building blocks of managerial decisions and actions that determine long-run performance.

Within a supply chain, resources and strategies include those that reflect interfirm activity. We therefore propose that operations capability and corresponding supply chain management practices play distinct roles in contributing to 


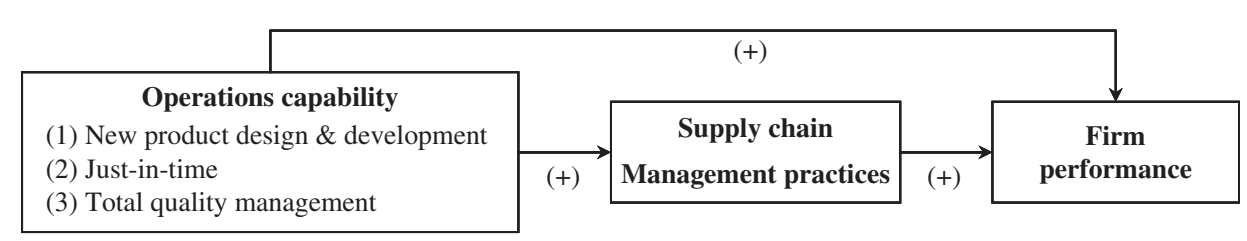

Figure 1. Conceptual framework.

firm performance. We further propose that operations capability is an antecedent of these supply chain management practices, and that insight into the relationship between capability and supply chain management practice can lead to a better understanding of the relationship between operations capability and firm performance. As several authors have suggested, the development of internal operations capabilities are the primary vehicle for operational excellence within a firm (e.g., Hammer and Champy 1990, Morash and Clinton 1998). A logical extension is that once a firm has developed its internal operations capabilities and infrastructure, it is in a position to leverage relationships within the supply chain. While the supply chain management literature debates extensively about collaborative, inter-firm development of supply chain capabilities, the reality is that firms typically develop an internal focus prior to involving external partners. The implication however, is that how a firm manages its supply chain should be considered simultaneously with consideration of the relationship between internal operations capability and firm performance. The conceptual framework underlying the study is presented in figure 1.

\subsection{Content of operations capability}

Operations capability refers to the tasks and activities at which firms must excel in support of corporate objectives (e.g., Dierickx and Cool 1989, Safizadeh et al. 2000). While the literature often fails to distinguish capability from competitive priorities or manufacturing competence, the underlying premise is that capabilities reflect how the operations function serves as a source of value to an organization. (Competitive priorities are dimensions of operations that firms believe to be important to success (e.g., Safizadeh et al. 2000, Boyer and Lewis 2002). Manufacturing competence is the extent to which manufacturing supports corporate objectives, (e.g., Cleveland et al. 1989, Vickery et al. 1993) The literature has focused primarily on the nature of capability, identifying the core dimensions of capability such as quality, price, flexibility and delivery, relevant to enhanced competitiveness (e.g., Leong, et al. 1990, Ward et al. 1998). Those studies that have addressed the content of capability however, the focus of this study, point to process improvement programs related to just-in-time, quality management, and new product development, in addition to information and process technology capabilities (e.g., De Meyer et al. 1989, Roth and Miller 1992, Hayes and Pisano 1996, Narasimhan and Jayaram 1998). We thus define operations capability in terms of a firm's new product design and development, just-in-time, and total quality management capabilities. While there may be other dimensions of capability, these three have the properties that they are rooted in the operations domain, documented in the literature (e.g. Tan et al. 2004), 
unique to a firm, and have been demonstrated to be sources of sustainable competitive advantage.

\section{Hypotheses development}

\subsection{Operations capability and supply chain management practices}

Several studies have demonstrated a relationship between new product design and development (NPDD) activities and management of the supply chain. For example, McGinnis and Vallopra (1999) proposed that purchasing and supplier involvement in NPDD is a source of competitive advantage. Ettlie and Sethuraman (2002) showed that NPDD intensity and the resulting percentage of revenue generated are directly related to levels of global sourcing. Ragatz et al. (2002) demonstrated that early supplier involvement in NPDD leads to significant improvements in cost, quality, and cycle time across the supply chain when customers have clear goals and specifications. Cox et al. (2002) concluded that in the context of product innovation and supply chain management in the food processing and distribution industry, longterm relationships among firms, customers, and suppliers using information sharing networks would become more widespread in a demand-driven environment. Randall et al. (2003) examined the relationship between product demand characteristics and initial supply chain investments during market entry. Results showed that firms account for characteristics such as market growth, product variety, contribution margins and uncertainty when first considering supply chain investments. Tatikonda and Stock (2003) used organizational theory to develop a conceptual model of the determinants of successful product technology transfer. They proposed that product technology transfer is most effective when there is a good fit between the type of technology being transferred and the organizational interactions between the source and recipient of the technology.

A firm that actively involves key suppliers in design and development efforts must effectively manage its supply chain. Sharing information, technology and risk are contingent on having sound relationships with potential partners. Effectively incorporating supplier parts into new products requires careful evaluation of how they will interface. The potential for cost savings and quality improvements will be limited without a shared understanding of how partners plan to align their individual goals to meet shared objectives. We therefore hypothesize:

$\mathrm{H}_{1 \mathrm{a}}$ : New product design and development capability positively affects supply chain management practices.

3.1.1 Just-In-time and supply chain management practices. Olhager (2002) argued that supply chain efficiency is contingent on the effectiveness and ability of individual supply chain members to connect. The author analysed supply chain management from a just-in-time perspective, focusing on linkages between supply chain members and the chain's collective efficiency. Results showed that lead-time conformity has a greater impact on supply chain lead-time performance than processing time equivalency. Yang and Pan (2004) proposed an integrated inventory management model for managing just-in-time inventory in environments where 
supply chain members form strategic alliances for the purpose of profit sharing. Balsmeier and Voisin (1996) discussed the importance of rapid delivery of products, and how just-in-time manufacturing principles can be applied to supply chain management practices. They stressed that inter-organization competition for final consumers will soon be replaced by the concept of inter-supply chain competition for consumers, making it insufficient to solely focus on a firm's internal competencies.

Numerous examples exist of a firm's just-in-time capability influencing its supply chain management practices. Just-in-time manufacturers are expected to deliver raw materials and/or component parts in small lot sizes, frequently, and directly to the point of use, eliminating the need for incoming inspection and warehousing, and reducing material movements. However, the reductions in inventory also mean that manufacturers must ensure that incoming materials and component parts are of the quality and quantity expected, and that deliveries are on-time. To achieve this, many organizations adopt relationships with key suppliers to share confidential information and technology. Instead of relying on inspection of incoming materials and component parts, they certify strategic suppliers' processes and/or products. A firm with advanced just-in-time capability is likely to place significant emphasis on such practices. Based on these observations we hypothesize:

$\mathrm{H}_{1 \mathrm{~b}}$ : Just-in-time capability positively affects supply chain management practices.

3.1.2 Total quality management and supply chain management practices. Romano (2002) stressed that quality certification is a necessity for firms to compete, and that quality is a strategic variable that should be considered and managed across the entire supply chain. González-Benito et al. (2003) explored connections between buyer and supplier quality assurance practices among automotive component suppliers. Their results highlighted the importance of a commitment to quality assurance from all firms within the supply chain. Gunasekaran and McGaughey (2003) examined relationships between total quality management and supply chain management such as operational flexibility and performance measurement. Several research areas involving total quality management and supply chain management were suggested to be worthy of further research. Kanji and Wong (1999) investigated relationships between total quality management and supply chain management and concluded that failure to consider the impact of total quality management programs helps to explain the inadequacies of existing models of supply chain management. Kannan and Tan (2005) also highlighted the inherent relationships between quality management and supply chain management practices.

The rationale for the relationship between a firm's total quality management capability and its supply chain management practices is apparent. For example, a firm with advanced quality management capability is likely to select suppliers that are similarly competent. They will be motivated to form alliances with such suppliers and allow them to participate in new product design and development initiatives. Conversely, a firm that is less advanced in its capability is unlikely to be invited to do so due to its lack of capability, motivation to improve, and credibility in the eyes of suppliers. We therefore hypothesize:

$\mathrm{H}_{1 \mathrm{c}}$ : Total quality management capability positively affects supply chain management practices. 


\subsection{Operations' capability and firm performance}

3.2.1 New product design and development capability and firm performance. New product design and development capability has been shown to yield multiple advantages such as operations synergies (Palepu 1985), economies of scope (Ghoshal 1987), the creation of inimitable resources (Barney 1991), the effective transfer of core competencies (Prahalad and Hamel 1990), and financial synergies (Majid and Myers 1987). Zirger and Hartley (1996) and Griffin (1997) showed that companies benefit from product development practices such as part standardization that can simultaneously lead to improvements in inventory, cost, and quality performance. New product design and development activities are also associated with increased customer satisfaction (Chase et al. 1998). Recent evidence shows that leading-edge firms have shifted their quality emphasis from relying on quality inspection to designing quality into the product (Tan 2001). Designing quality into the product recognizes that quality efforts in the design phase yield benefits in manufacturability, thereby reducing total quality costs and enhancing firm performance. Doing so, particularly when implemented concurrently with other strategic operations practices, can be a source of competitive advantage. While there is a lack of empirical evidence to support the relationship between new product development capability and firm performance, the literature and anecdotal evidence from industry suggest that new product design and development capability will positively firm performance. We therefore, hypothesize:

$\mathrm{H}_{2 \mathrm{a}}$ : New product design and development capability positively affects firm performance.

3.2.2 Just-in-time capability and firm performance. The role of just-in-time capability as a contributor to firm performance is well documented. It is based on the notion that simplifying manufacturing processes and reducing variation eliminates waste, thereby reducing cost and lead times and increasing quality. This in turn leads to improvements in measures of firm performance (e.g., Nakamura et al. 1998, Callen et al. 2000, Fullerton and McWatters 2001). Kim and Ha (2003) showed that optimal just-in-time delivery policies, when adopted by both buyers and suppliers in a cooperative manner, were economically beneficial to both parties.

Various just-in-time practices, including setup time reduction, process standardization, preventive maintenance, frequent deliveries of small lot sizes, continuous improvement efforts, and top management involvement have been observed in the manufacturing sector (e.g., Flynn et al. 1995, Germain and Dröge 1997). While the capability and extent of just-in-time implementation differs by firm, industry and manufacturing environment (Lee and Ebrahimpour 1984), firms that are more advanced in their capabilities can be expected to use resources more efficiently and effectively, thereby yielding greater benefits. Consistent with the literature, we therefore hypothesize:

$\mathrm{H}_{2 \mathrm{~b}}$ : Just-in-time capability positively affects firm performance. 
3.2.3 Total quality management and firm performance. The relationship between total quality management and firm performance is also well established (e.g., Anderson et al. 1994, Anderson et al. 1995, Flynn et al. 1995, Ahire et al. 1996, Dow et al. 1999). Recent studies have however investigated the relationship from different perspectives. For example, the resource-based view of the firm (Escrig Tena et al. 2001) suggests that the relationship is the result of the unique resources and competencies generated by the implementation of total quality management. These competencies are viewed as sources of sustainable competitive advantage and therefore contribute to improved performance. Das et al. (2000) utilized the neoclassical perspective of the influence of competitive environment to develop an integrative framework of total quality management. Their results showed that significant investments in quality are necessary to achieve high levels of customer satisfaction when firms face moderate to high competition. Samson and Terziovski (1999) took a behavioral science perspective, concluding that leadership, management and customer focus are significant predictors of operational performance. Chang et al. (2003) showed that the congruence of business strategy, quality dimensions, and capability is vital to firm performance on the dimensions of new product introduction, net profit and sales. Consistent with prior findings, we therefore hypothesize:

$\mathrm{H}_{2 \mathrm{c}}$ : Total quality management capability positively affects firm performance.

\subsection{Supply chain management practices and firm performance}

Tan et al. (1998) examined the relationship between operational quality practices, supply chain management practices, and firm performance. They concluded that quality management and supply chain management techniques and tools must be implemented concurrently to achieve superior financial and business performance. Vickery et al. (2003) investigated the performance implications of an integrated supply chain management strategy. They concluded that positive direct and indirect relationships exist between supply chain integration and financial performance. Tan (2002) studied the concerns of supply chain managers, concluding that certain supply chain management practices positively impact firm performance. In a related study, Wisner (2003) developed a theoretical framework for supplier and customer management, and demonstrated a positive relationship between supply chain management and firm performance.

The literature is replete with examples of firms that have downsized to focus on core competencies, and attempted to achieve superior competitive advantage by capitalizing on exceptional supplier capability and technology (Prahalad and Hamel 1990). These organizations have reduced their supply bases to more effectively manage relationships with strategic suppliers and develop mutually beneficial partnership relationships (Tully 1995). Superior supplier capability can lead to reduced product development lead time, exceptional quality and rapid integration of new technologies (Tan 2001, Ragatz et al. 2002). By increasing outsourcing activities, these organizations rely to a greater extent on their partners and must therefore effectively manage their supply chains to remain competitive. We thus hypothesize:

$\mathrm{H}_{3}$ : Supply chain management practices positively affect firm performance. 


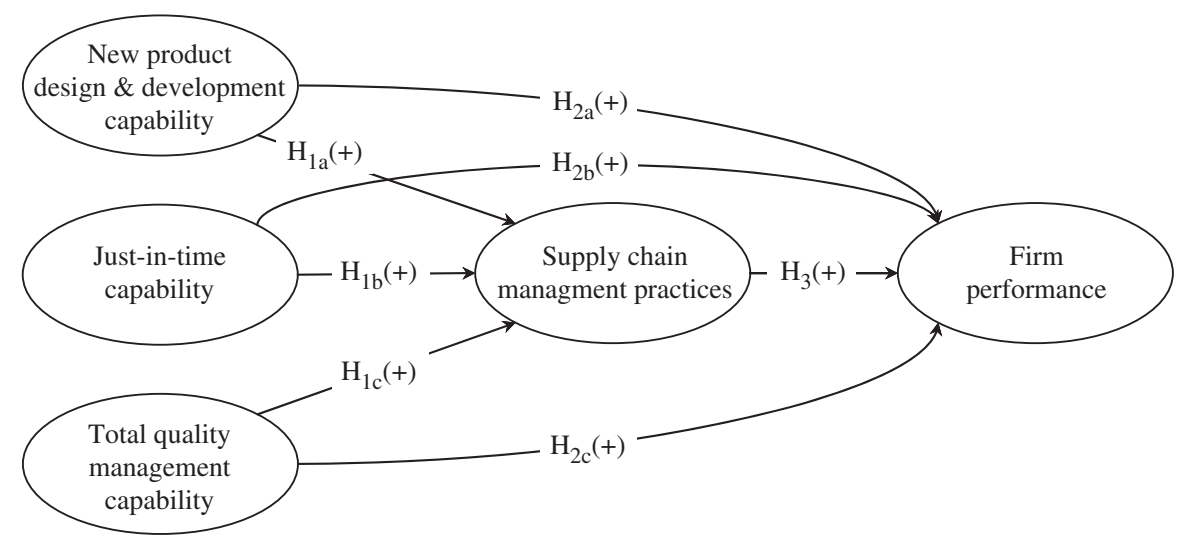

Figure 2. Proposed research model.

Figure 2 and table 1 summarize the proposed hypothesized model and the key literature as it relates to the hypotheses of interest.

\section{Methodology}

\subsection{Survey instrument and data collection}

In addition to the literature review, in-depth interviews with operations and purchasing managers were used to identify pertinent dimensions of the constructs of interest. Interviews help to ensure that the constructs of interest and the associated relationships, as reported in the literature, are consistent with industry practice. A draft survey instrument was reviewed by a sample of academics with relevant expertise, to obtain feedback on the comprehensiveness, clarity, face validity, and readability of the scales and survey instructions. Based on the feedback, a modified instrument was developed and tested by thirty senior managers. In response to their feedback, further minor changes were made.

The resulting instrument was sent to 4500 senior purchasing and operations managers identified from the Institute for Supply Management (ISM) and the Association for Operations Management (APICS) membership lists. Lists were pre-screened to identify only respondents likely to be familiar with their firm's supply chain and operations strategy practices. The original mailing followed by a reminder postcard and a second mailing of the survey (Dillman 1999) yielded 455 usable observations $(10.11 \%$ response rate). To test for nonresponse bias, $\mathrm{t}$ tests of random samples of early and late returned surveys were tested for statistically significant differences in the sales and size of the firms. Late returned surveys can be considered to be representative of nonrespondents (Lambert and Harrington 1990). No statistically significant differences $(\alpha=0.05)$ between the two samples suggests the absence of nonresponse bias. 


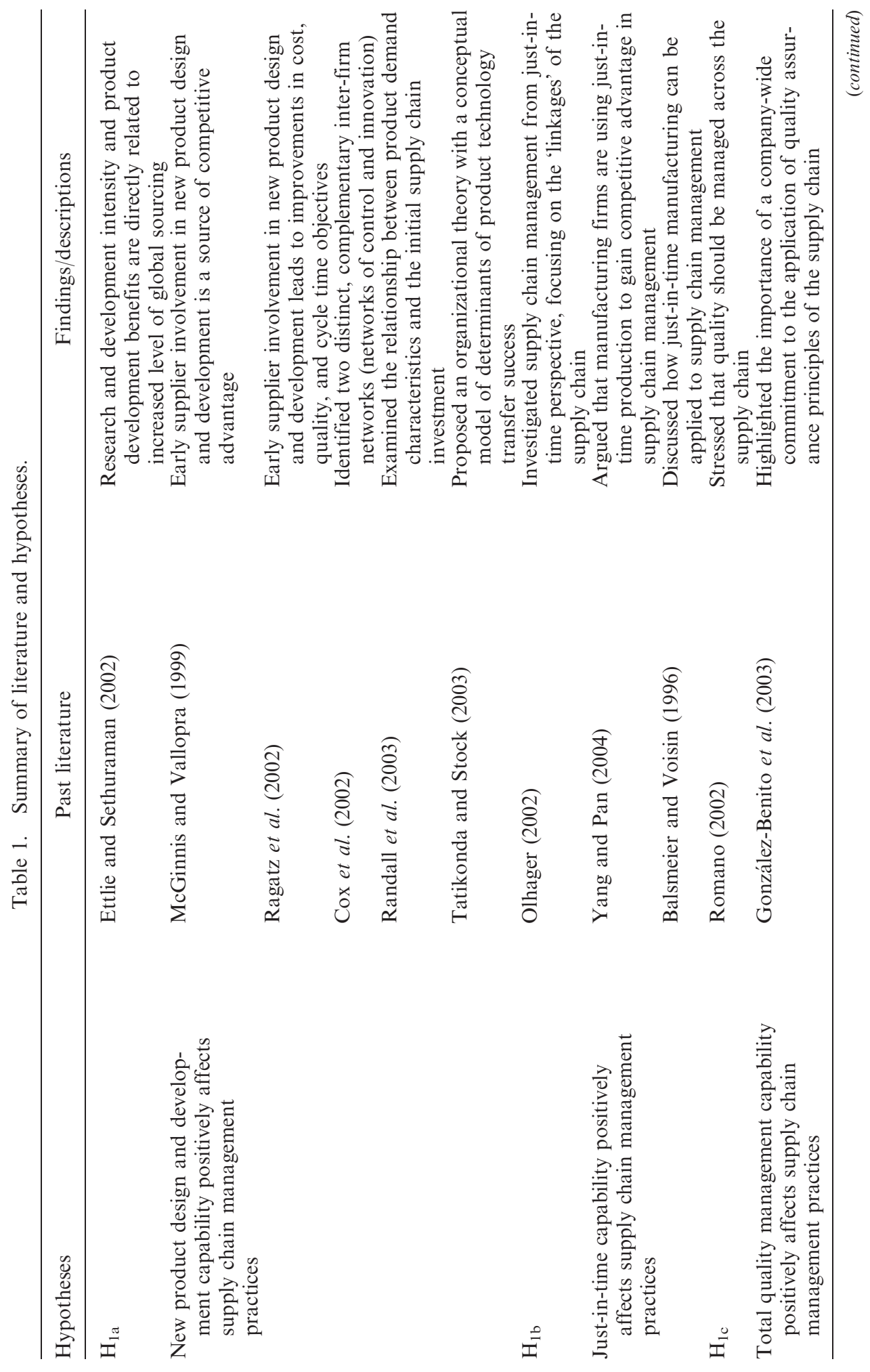




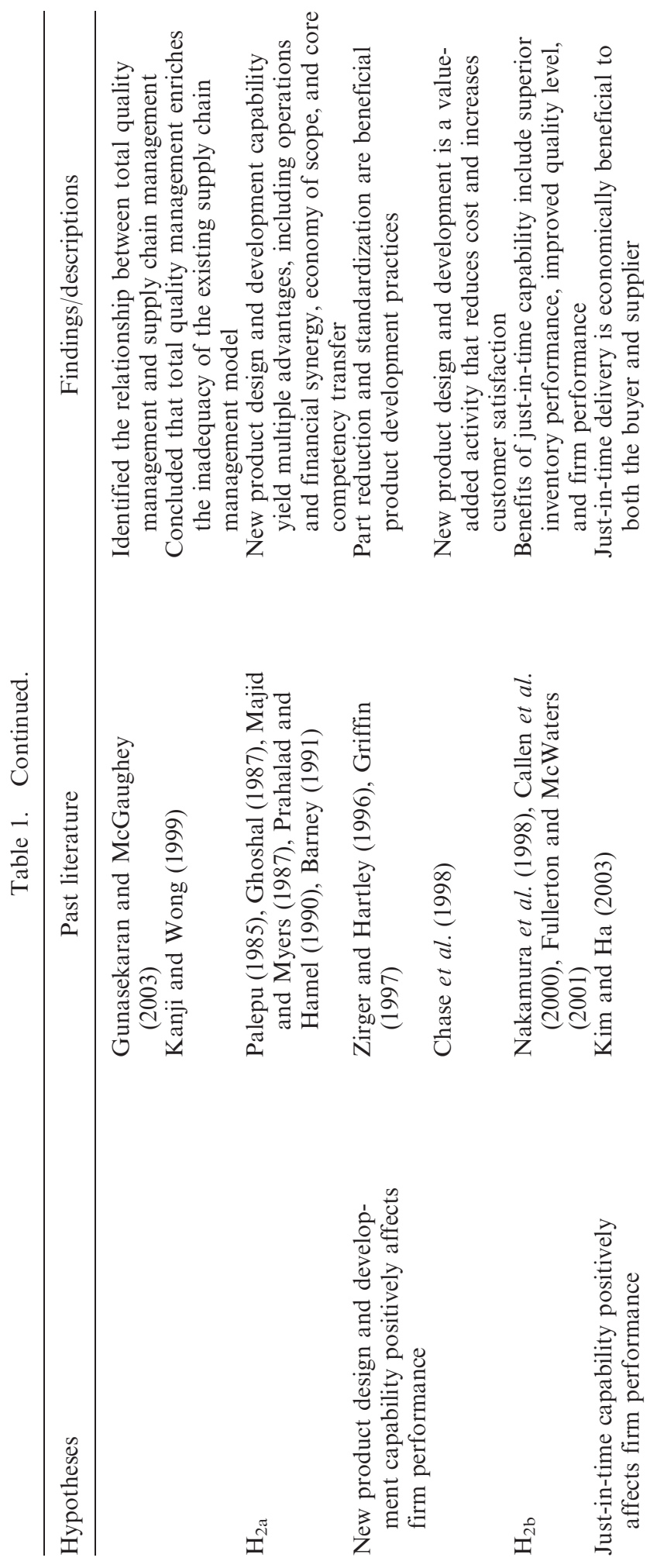




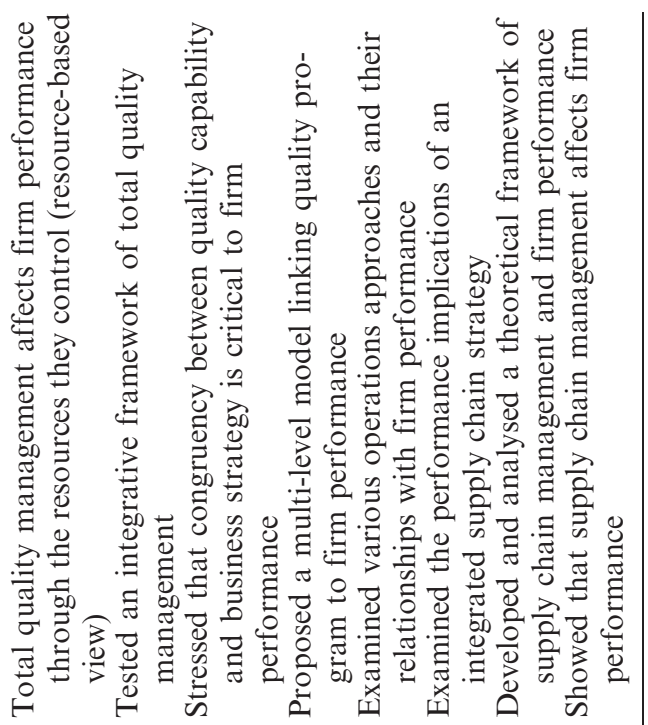

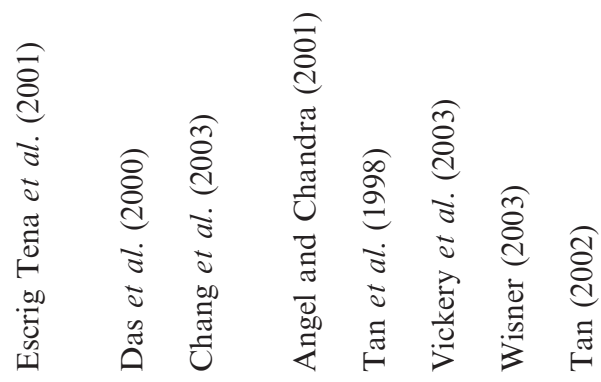

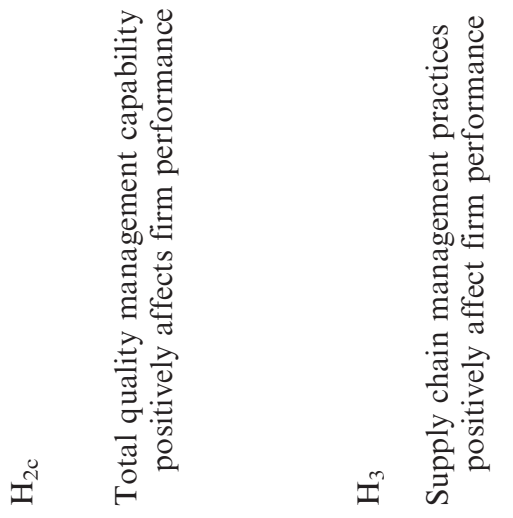




\subsection{The measures}

To achieve a high degree of validity, multiple indicators were used to represent each construct (table 3, column 1). For each construct, respondents were asked to indicate on a five-point Likert scale $(1=$ low, $5=$ high), the importance of each practice in their firm. For firm performance, respondents were asked to indicate their firm's performance compared to that of major competitors. Correlation analysis was used to compare responses of a sample of firms to published financial data. Results indicated that correlation was statistically significant $(\alpha=5 \%)$.

\subsection{Statistical analysis}

A three-phase statistical analysis was adopted. LISREL 8.30 (Jöreskog and Sörbom 1993) was first used to perform confirmatory factor analysis of each construct. Internal consistencies were estimated using Cronbach's $\alpha$ (Cronbach 1951), and convergent validity was established by ensuring item loadings were significant. Three-step mediated regression analysis (Baron and Kenny 1986) was used to examine the mediation effects of supply chain management practices. The mediator (supply chain management practice) was first regressed on the independent variables (operations capabilities). The dependent variable (firm performance) was then regressed on the independent variables. Finally, the dependent variable was regressed simultaneously on the independent variables and the mediator. Mediation effects exist if the independent variables are related to the mediator and dependent variable, and the mediator affects the dependent variable (Baron and Kenny 1986). The relationship between the independent variables and the dependent variable must be weaker when the mediating variable is considered than when it is not. Complete mediation is said to exist if the independent variables have no statistically significant effect on the dependent variable when the mediator is controlled for. Partial mediation exists if the statistically significant effects of the independent variables on the dependent variable are smaller when the mediator is controlled for. In the third phase, structural equation modelling was used to simultaneously assess the psychometric properties of the scaled items for each construct, and to establish the relationships between the exogenous and endogenous variables.

\section{Results}

The zero-order correlation matrix for the five constructs (table 2) shows that correlations are statistically significant $(\alpha=5 \%)$ and show the expected positive relationships. This provides preliminary support for the relationships depicted in figure 2. All correlation coefficients are less than 0.50 , suggesting that multicollinearity is not present (Mason and Perreault 1991).

\subsection{Phase one analysis}

Results of confirmatory factor analysis provide support for the measurement models. Although the $\chi^{2} p$-value is statistically significant $\left(\chi_{\text {d.f. }}^{2}={ }_{220}=565.42, p<0.01\right)$, the ratio of $\chi^{2}$ to the degrees of freedom of 2.57 is less than 3 , indicating that the data fit 
Table 2. Correlation matrix of latent constructs.

\begin{tabular}{lcccc}
\hline Latent constructs & $\begin{array}{c}\text { Just-in-time } \\
\text { capability }\end{array}$ & $\begin{array}{c}\text { Total quality } \\
\text { management } \\
\text { capability }\end{array}$ & $\begin{array}{c}\text { Supply chain } \\
\text { management } \\
\text { practices }\end{array}$ & $\begin{array}{c}\text { Firm } \\
\text { performance }\end{array}$ \\
\hline $\begin{array}{l}\text { New product design and } \\
\text { development capability }\end{array}$ & 0.497 & 0.451 & 0.301 & 0.312 \\
$\begin{array}{l}\text { Just-in-time capability } \\
\begin{array}{c}\text { Total quality management } \\
\text { capability }\end{array}\end{array}$ & - & 0.495 & 0.304 & 0.282 \\
$\begin{array}{l}\text { Supply chain management } \\
\text { practices }\end{array}$ & - & & 0.259 & 0.363 \\
\hline
\end{tabular}

All coefficients significant at $\alpha=5 \%$.

the hypothesized model well. Many researchers emphasize the need to relax the interpretation of $\chi^{2}$ statistics, especially when sample size is large. Indeed, most recent structural equation modelling studies use the ratio of $\chi^{2}$ to degrees of freedom as the preferred fit index (e.g., Byrne 1988, Hu and Bentler 1995).

Values of Cronbach's $\alpha$ (table 3) for the constructs range from 0.7064 for firm performance to 0.8630 for new product design and development capability, suggesting that the scales are reliable (Bollen 1989). Some critics argue that Cronbach's $\alpha$, which is used to test the reliability of a measure based on internal consistency, does not adequately estimate errors caused by factors external to an instrument such as differences in testing situations and respondents over time. In the context of structural equation modelling, it has been suggested that composite reliability and average variance extracted be used since they are more parsimonious than Cronbach's $\alpha$ (Netemeyer et al. 1990). Statistics for composite reliability (table 3 ) for the five constructs exceed the required value of 0.60 . With the exception of the supply chain management practices construct, all average variances extracted exceed the threshold level of 0.50 . Taken together, these three statistics suggest that all constructs are sufficiently reliable.

Measurement models were tested for convergent, discriminant, and nomological validity. Four of the five models yielded values for average variance extracted in excess of 0.50 (table 3), suggesting excellent convergent validity (Shock et al. 2004). The test for discriminant validity involves examining correlations between pairs of latent variables (Anderson and Gerbing 1988). If variables are distinct, correlations should be unidimensional and significantly less than one. All correlation coefficients are significant and less than 0.5 (table 2), thus discriminant validity can be assumed. Nomological validity is suggested by the values of the RMSEA, GFI, AGFI, NNFI, CFI, and IFI fit indices. The analysis thus suggests that the measurement models are acceptable for reproducing the population covariance matrices (Steiger 1990).

\subsection{Phase two analysis}

Results of the mediated regression analysis are shown in table 4. In model 1, the dependent variable, supply chain management practices, was regressed as the mediator on the three predicted antecedents (i.e., operations capabilities). The model was statistically significant, operations capabilities accounting for $12.9 \%$ of the 
Table 3. Constructs, reliabilities and average variance extracted.

\begin{tabular}{|c|c|c|c|}
\hline Latent constructs and measured variables & Cronbach's $\alpha$ & $\begin{array}{l}\text { Composite } \\
\text { reliability }\end{array}$ & $\begin{array}{l}\text { Average } \\
\text { variance } \\
\text { extracted }\end{array}$ \\
\hline $\begin{array}{l}\text { New product design and development capability } \\
\text { 1. Early supplier involvement } \\
\text { 2. Concurrent engineering } \\
\text { 3. Simplification of parts } \\
\text { 4. Value analysis/value engineering }\end{array}$ & 0.8630 & 0.8767 & 0.6404 \\
\hline $\begin{array}{l}\text { Just-in-time capability } \\
\text { 1. Reducing supplier base } \\
\text { 2. Increasing delivery frequencies } \\
\text { 3. Reducing inventory to expose problems }\end{array}$ & 0.7873 & 0.8089 & 0.5855 \\
\hline $\begin{array}{l}\text { Total quality management capability } \\
\text { 1. Employee training in quality } \\
\text { 2. Employee empowerment } \\
\text { 3. Communication of quality goals } \\
\text { 4. Emphasis on quality instead of price }\end{array}$ & 0.8556 & 0.8810 & 0.6510 \\
\hline $\begin{array}{l}\text { Supply chain management practices } \\
\text { 1. Increase suppliers' just-in-time capabilities } \\
\text { 2. Participating in sourcing decisions } \\
\text { 3. Geographical proximity of suppliers } \\
\text { 4. Formal information-sharing agreements } \\
\text { 5. Improving the integration of activities } \\
\text { 6. Searching for new ways for integration } \\
\text { 7. Communicating future strategic needs } \\
\text { 8. On-time delivery } \\
\text { 9. Reducing response time }\end{array}$ & 0.7518 & 0.7622 & 0.3846 \\
\hline $\begin{array}{l}\text { Firm performance } \\
\text { 1. Average selling price } \\
\text { 2. Overall product quality } \\
\text { 3. Overall competitive position }\end{array}$ & 0.7064 & 0.7599 & 0.5173 \\
\hline Acceptable level & $\geq 0.70$ & $\geq 0.60$ & $\geq 0.50$ \\
\hline
\end{tabular}

variance in supply chain management practices. Coefficients for new product design and development capability $(\beta=0.173)$ and just-in-time $(\beta=0.170)$ were statistically significant $(\alpha=0.05)$ and in the predicted positive directions, thus meeting the first requirement to infer mediation effects. The coefficient for total quality management capability was statistically insignificant, suggesting a lack of mediation effect between total quality management and supply chain management practices. The preliminary conclusion to be drawn is that new product design and development capability and just-in-time capability have a similar effect on supply chain management practices. The implication is that firms should critically review their new product design and development and just-in-time capabilities when adopting and implementing supply chain management practices.

In model 2, firm performance was regressed on the three predicted antecedents. The three independent variables accounted for $16.3 \%$ of the variance in firm performance. Regression coefficients for new product design and 
Table 4. Mediated regression analysis.

\begin{tabular}{|c|c|c|c|}
\hline & Model 1 & Model 2 & Model 3 \\
\hline & $\begin{array}{c}\text { Supply chain } \\
\text { management } \\
\text { practices }\end{array}$ & $\begin{array}{c}\text { Firm } \\
\text { performance }\end{array}$ & $\begin{array}{l}\text { Firm } \\
\text { performance }\end{array}$ \\
\hline \multicolumn{4}{|c|}{ Predicted antecedents (operations capability) } \\
\hline $\begin{array}{l}\text { New product design and } \\
\text { development capability }\end{array}$ & $0.173^{*}$ & $0.160^{*}$ & $0.144^{*}$ \\
\hline Just-in-time capability & $0.170^{*}$ & 0.077 & 0.062 \\
\hline Total quality management capability & 0.097 & $0.253^{*}$ & $0.244^{*}$ \\
\hline \multicolumn{4}{|l|}{ Mediator } \\
\hline Supply chain management practices & & & $0.092 *$ \\
\hline$F$ & $22.21 *$ & $29.38 *$ & $23.19 *$ \\
\hline$R^{2}$ & $12.9 \%$ & $16.3 \%$ & $17.1 \%$ \\
\hline Adjusted $R^{2}$ & $12.3 \%$ & $15.8 \%$ & $16.4 \%$ \\
\hline
\end{tabular}

* Parameters/coefficients statistically significant at $\alpha=5 \%$.

development $(\beta=0.16)$ and total quality management capability $(\beta=0.253)$ were statistically significant and in the expected positive direction, but the coefficient for just-in-time capability was insignificant. These results suggest that total quality management capability has a larger direct impact on performance than new product design and development capability. This is consistent with the literature that suggests that the benefits of new product development on performance are usually gained through effective supply chain management practices such as early supplier involvement, information sharing, and leveraging supplier technologies and capabilities.

When the supply chain management practices construct was added to the regression model (model 3), the variance explained by the data increased to $17.1 \%$. The revised model and the supply chain management practices coefficient $(\beta=0.092)$ were both statistically significant $(\alpha=0.05)$. As expected, the coefficient for new product design and development capability decreased (from 0.160 to 0.144 ) because of the mediation effect of supply chain management practices. This implies that supply chain management practices not only partially mediate the relationship between new product design and development capability and performance, supporting hypotheses $\mathrm{H}_{1 \mathrm{a}}, \mathrm{H}_{2 \mathrm{a}}$ and $\mathrm{H}_{3}$, they completely mediate the relationship between just-in-time capability and firm performance, supporting hypotheses $\mathrm{H}_{1 \mathrm{~b}}$ and $\mathrm{H}_{3}$. However hypothesis $\mathrm{H}_{2 \mathrm{~b}}$ was not supported. The results also show that supply chain management practices are not a mediator of the relationship between total quality management capability and firm performance $\left(\mathrm{H}_{1 \mathrm{c}}\right)$. The direct impact of total quality management capability on firm performance is however evident from models 2 and $3\left(\mathrm{H}_{2 \mathrm{c}}\right)$.

\subsection{Phase three analysis}

Structural equation modelling was used to predict parameter estimates of the hypothesized model and to provide further support for the hypotheses tested in the 


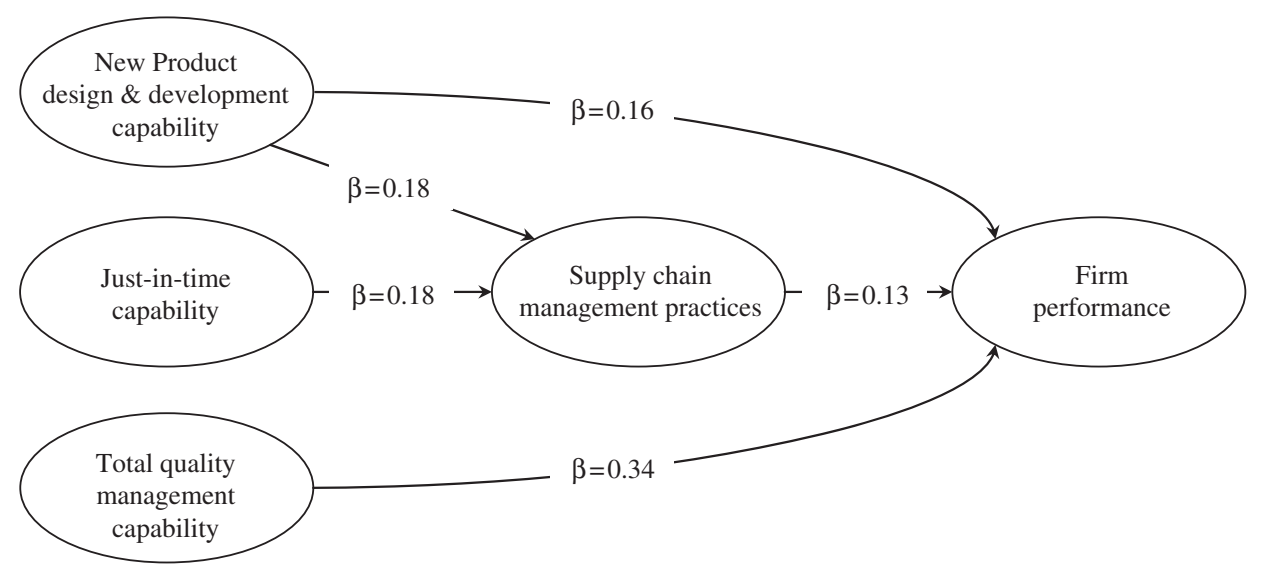

Figure 3. Path model parameter estimates.

second phase analysis (figure 3). Standardized parameter estimates for the paths from new product design and development $(\beta=0.18)$ and just-in-time $(\beta=0.18)$ capability to supply chain management practices were statistically significant $\left(\alpha=5 \%\right.$ ), providing further support for hypotheses $\mathrm{H}_{1 \mathrm{a}}$ and $\mathrm{H}_{1 \mathrm{~b}}$. There was insufficient evidence to support hypothesis $\mathrm{H}_{1 \mathrm{c}}$ due to the insignificant path coefficient between total quality management capability and supply chain management practices. The standardized parameter estimate for the path between new product design and development capability and firm performance $(\beta=0.16)$ was statistically significant, providing further support for hypothesis $\mathrm{H}_{2 \mathrm{a}}$. Similarly, the standardized parameter estimate for the path from total quality management capability to firm performance $(\beta=0.34)$ was statistically significant, providing additional support hypothesis $\mathrm{H}_{2 \mathrm{c}}$. The insignificant estimate for the path from justin-time capability to firm performance again suggests an absence of evidence to support hypothesis $\mathrm{H}_{2}$. Support for hypothesis $\mathrm{H}_{3}$ exists by virtue of the significant path coefficient from supply chain management practices to firm performance $(\beta=0.13)$. Squared multiple correlations for firm performance $(0.28)$ and the significance or otherwise of parameter estimates, closely match results obtained from the mediated regression analyses.

\section{Discussion}

Significant path relationships for new product design and development capability show that this capability has both direct and indirect effects on firm performance. A primary reason for manufacturing firms to continuously engage in new product design and development is that the life cycle of most consumer products is becoming ever shorter in today's competitive environment. After years of discovery, development, testing, and commercialization, generic alternative products often appear soon after patent protections have expired. To remain competitive, bringing high-quality new products to market before competitors do is crucial. 
Firms attempting to nurture effective new product design and development capabilities should not overlook the important role that effectively managing the supply chain can have. Internally executed practices such as concurrent engineering, part simplification, and value analysis/engineering, can, in and of themselves, positively impact development efforts and thereby performance. However, new technologies are emerging which may require specialized knowledge and expertise, as well as significant capital and a willingness to assume risk. In addition, increased product offerings and customer expectations make it difficult for firms acting on their own to bring potentially successful products to market in a timely, competitive manner. They are therefore reliant on the active participation, from the early stages of the development process, of key suppliers. This in turn implies a need to identify and develop relationships with suppliers with the requisite knowledge. Firms are unlikely to make the commitment to doing so unless goals, strategies, and expectations are aligned.

The direct impact of just-in-time capability on firm performance was not confirmed. This result is not altogether surprising. Past research has suggested that the positive impact of just-in-time practices on performance is attributable to infrastructural decisions made as part of broader quality management initiatives (Sakakibara et al. 1997). However, the analysis does demonstrate that just-in-time capability impacts firm performance indirectly through supply chain management practices. This may help to explain why some just-in-time implementations fail to enhance performance. Typical just-in-time practices such as reducing the supplier base, increasing delivery frequency, and lowering inventory levels, cannot be successfully implemented without the assistance of suppliers. For example, reducing inventory levels by increasing delivery frequency requires suppliers to be located close to the buyer and/or to be willing to deliver in small quantities. It also requires the sharing of information on production schedules. The viability of small lot delivery also relies heavily on the buyer having confidence in the supplier's ability to achieve high quality levels. This will not typically occur unless there is a prior relationship between the buyer and supplier and a commitment to working together to resolve quality and delivery problems. Additionally, early supplier involvement is critical to ensure that quality, technical, and cost issues are addressed during product development.

The results do not indicate a significant relationship between total quality management capability and supply chain management practices, but suggest that quality capability affects firm performance directly. A possible explanation for this surprising finding is that the measures used to assess total quality management capability relate to internally focused quality initiatives and do not explicitly address boundary spanning quality issues such as supplier quality. As such, the results should not be interpreted as suggesting that firms should focus only on internally quality. Prior research has suggested that supplier driven quality and a focus on customer needs can have a positive impact on performance (e.g., Anderson et al. 1994, 1995, Flynn et al. 1995, Ahire et al. 1996). For example, certifying suppliers' products and processes, participating in continuous improvement efforts with suppliers, involving customers in product development efforts, and implementing systems that measure and manage customer satisfaction, are all important elements of a quality management program. 


\section{Conclusions}

This study provides empirical support for the central thesis that supply chain management practices mediate the impact of operations capability on performance. This is consistent with resource-based and competence-based views of the firm, and for resource-advantage theory as it relates to manufacturing success. Supply chain management practices allow firms to take advantage of their manufacturing capabilities by leveraging the expertise and cooperation of key members of their supply chains. This allows them to achieve performance levels in excess of those they might achieve by relying solely on their internal capabilities. This finding is important since it not only helps managers to recognize how to better leverage internal capabilities by exploiting relationships with supply chain partners, it highlights the need to hone these capabilities prior to focusing on the extended enterprise. The coordination of internal capabilities with support from key partners provides the basis for creating the inimitable resource base that is critical to sustainability. As such the results demonstrate that supply chain management is a key to sustainable competitive advantage. The study also provides further evidence of the direct influence of operations capability and supply chain management practices on firm performance and on the need to examine operations capability in a broader, supply chain context.

The research is not without its limitations. The proposed model does not consider performance from multiple perspectives. For instance, it does not consider variables such as market structure from the industrial organization literature, ownership structure from the finance literature, or corporate governance from the organizational behaviour literature. The use of longitudinal data would also have been useful to determine whether the effects of variables in the model are short-term or endure over time. Such data would also be useful for examining how changes in certain variables affect performance. A model that uses changes in antecedents (operations capabilities) and changes in consequence (performance) may yield more interesting results, since dynamic formulation eliminates the influence of variables whose levels are stable over time. Moreover, a lagged relationship between variables over time would help to pinpoint causation in the model. Future research also needs to explore additional facets of operations capability, such as logistics and purchasing capability.

\section{References}

Ahire, S.L., Golhar, D.Y. and Waller, M.A., Development and validation of TQM implementation constructs. Deci. Sci., 1996, 27, 23-56.

Anderson, J.C., Rungtusanatham, M. and Schroeder, R.G., A theory of quality management underlying the Deming method. Acad. Mgmt. Rev., 1994, 19, 472-509.

Anderson, J.C., Rungtusanatham, M., Schroeder, R.G. and Devaraj, S., A path analytic model of a theory of quality management underlying the Deming management method: preliminary empirical findings. Deci. Sci., 1995, 26, 637-658.

Anderson, J.C. and Gerbing, D.W., Structural equation modeling in practice: a review and recommended two-step approach. Psychol. Bull., 1988, 103, 411-423.

Balsmeier, P.W. and Voisin, W.J., Supply chain management: a time-based strategy. Ind. Mgmt., 1996, 38, 24-27.

Barney, J., Firm resources and sustained competitive advantage. J. Mgmt., 1991, 17, 99-120.

Barney, J., Looking inside competitive advantage. Acad. Mgmt. Exec., 1995, 9, 49-61. 
Baron, R.M. and Kenny, D.A., The moderator-mediator variable distinction in social psychology research: conceptual, strategic, and statistical considerations. J. Personality Soc. Psychol., 1986, 5, 1173-1182.

Bollen, K.A., Structural Equations with Latent Variables, 1989 (New York: Wiley).

Boyer, K.K. and Lewis, M.W., competitive Priorities: investigating the need for trade-offs in operations strategy. Prod. Oper. Mgmt., 2002, 11, 9-20.

Byrne, B.M., Structural Equation Modeling with Lisrel, Prelis, and Simplis: Basic Concepts, Applications, and Programming, 1988 (Lawrence Erlbaum Associates: Mahwah).

Callen, J.L., Fader, C. and Krinsky, I., Just-in-time: a cross sectional plant analysis. Int. J. Prod. Econ., 2000, 63, 277-301.

Chang, S.C., Lin, N.P., Yang, C.L. and Sheu, C., Quality dimensions, capabilities and business strategy: an empirical study in high-tech industry. Total Quality Mgmt. Bus. Excellence, 2003, 14, 407-421.

Chase, R.B., Aquilano, N.J. and Jacobs, F.R., Production and Operations Management: Manufacturing and Services, 8th ed., 1998 (McGraw-Hill: Burr Ridge).

Cleveland, G., Schroeder, R.G. and Anderson, J.C., A theory of production competence. Dec. Sci., 1989, 20, 655-668.

Cool, K. and Schendel, D., Performance differences among strategic group members. Strategic Mgmt. J., 1988, 9, 207-223.

Cox, H., Mowatt, S. and Prevezer, M., New product development and product supply within a network setting: The chilled ready-meal industry in the UK. Ind. Innovation, 2002, 10, 197-217.

Cronbach, L.J., Coefficient alpha and the internal structure of tests. Psychometrika, 1951, 16, 297-334.

Das, A., Handfield, R.B., Calantone, R.J. and Ghosh, S., A contingent view of quality management: the impact of international competition on quality. Deci. Sci., 31, 649-691.

De Meyer, A., Nakane, J., Miller, J.G. and Ferdows, K., Flexibility: the next competitive battle. The manufacturing futures survey. Strategic Mgmt. J., 1989, 10, 135-144.

Dierickx, I. and Cool, K., Asset stock accumulation and sustainability of competitive advantage. Mgmt. Sci., 1989, 35, 1504-1510.

Dillman, D., Mail and Internet Surveys: The Tailored DESIGNED Method, 2nd ed., 1999 (John Wiley: New York).

Dow, D., Samson, D. and Ford, S., Exploding the myth: do all quality management practices contribute to superior quality performance? Prod. Oper. Mgmt., 1999, 8, 1-27.

Dutta., S., Narasimhan, O. and Rajiv., S., Success in high-technology markets: is marketing capability critical? Marketing Sci., 18, 547-568.

Escrig Tena, A.B., Bou Llusar, J.C. and Roca Puig, V., Measuring the relationship between total quality management and sustainable competitive advantage: a resource-based view. Total Quality Mgmt., 2001, 12, 932-938.

Ettlie, J.E. and Sethuraman, K., Locus of supply global manufacturing. Int. J. Oper. Prod. Mgmt., 2002, 22, 349-370.

Ferdows, K. and De Meyer, A., Lasting improvements in manufacturing performance: in search of a new theory. J. Oper. Mgmt., 1990, 9, 168-184.

Flynn, B.B., Sakakibara, S. and Schroeder, R.G., Relationship between JIT and TQM: practices and performance. Acad. Mgmt. J., 1995, 38, 1325-1360.

Flynn, B.B., Schroeder, R.G. and Sakakibara, S., The impact of quality management practices on performance and competitive advantage. Dec. Sci., 1995, 26, 659-691.

Fullerton, R.R. and McWatters, C.S., The production performance benefits from JIT implementation. J. Oper. Mgmt., 2001, 19, 81-96.

Germain, R. and Dröge, C., An empirical study of the impact of just-in-time task scope versus just-in-time workflow integration on organizational design. Deci. Sci., 1997, 28, 615-635.

Ghoshal, S., Global strategy: an organizing framework. Strat. Manage. J., 1987, 8(5), 425-441.

González-Benito, J., Martínez-Lorente, A.R. and Dale, B.G., A study of the purchasing management system with respect to total quality management. Ind. Marketing Mgmt., 2003, 32, 443-454. 
Grant, R.M., The resource-based theory of competitive advantage: implications for strategy formulation. California Mgmt. Rev., 1991, 33, 114-135.

Griffin, A., Modeling and measuring product development cycle time across industries. J. Engng Technol. Mgmt., 1997, 14, 1-24.

Gunasekaran, A. and McGaughey, R.E., TQM is supply chain management. TQM Magazine, 2003, 15, 361-363.

Hayes, R.H. and Pisano, G.P., Manufacturing strategy: at the intersection of two paradigm shifts. Prod. Oper. Mgmt., 1996, 5, 25-41.

Hu, L.T. and Bentler, P.M., Evaluating model fit. In Structural Equation Modeling: Concepts, Issues and Applications, edited by R.H. Hoyle, 1995 (Sage Publications: Thousand Oaks).

Jöreskog, K.G. and Sörbom, D., LISREL8: Structural Equation Modeling with the SIMPLIS Command Language, 1993 (Lawrence Erlbaum Associates: Hillsdale).

Kanji, G. and Wong, A.K., Business excellence model for supply chain management. Total Quality Mgmt., 1999, 10, 1147-1168.

Kannan, V.R. and Tan, K.C., Just in time, total quality management, and supply chain management: understanding their linkages and impact on business performance. OMEGA: Int. J. Mgmt. Sci., 2005, 33, 153-162.

Kim, S.L. and Ha, D.S., A JIT lot-splitting model for supply chain management: enhancing buyer-supplier linkage. Int. J. Prod. Econ., 2003, 86, 1-10.

Lambert, D.M. and Harrington, T.C., Measuring non-response bias in mail surveys. J. Bus. Logistics, 1990, 11, 5-25.

Lee, S.M. and Ebrahimpour, M., Just-in-time production system: some requirements for implementation. Int. J. Ops Prod. Mgmt., 1984, 4, 3-15.

Leong, G.K., Snyder, D.L. and Ward, P.T., Research in the process and content of manufacturing strategy. OMEGA: Int. J. Mgmt. Sci., 1990, 18, 109-122.

Majid, S. and Myers, S.C., Tax asymmetries and corporate income tax reforms. In Effects of Taxation on Capital Accumulation, edited by M. Feldstein, 1987 (University of Chicago Press: Chicago).

Mason, C.H. and Perreault, W.D., Collinearity, power, and interpretation of multiple regression analysis. J. Marketing Res., 1991, 28, 268-280.

McGinnis, M.A. and Vallopra, R.M., Purchasing and supplier involvement in process improvement: a source of competitive advantage. J. Supply Chain Mgmt., 1999, 35, $42-50$.

Nakamura, M., Sakakibara, S. and Schroeder, R., Adoption of just-in-time manufacturing at U.S. and Japanese owned plants: Some empirical evidence. IEEE Trans. Engng. Mgmt., 1998, 45, 230-240.

Nakane, J., Manufacturing Futures Survey in Japan: A Comparative Survey, 1983-1986, 1986 (Waseda University: Tokyo).

Narasimhan, R.N. and Jayaram, J., An empirical investigation of the antecedents and consequents of manufacturing goal achievement in North American, European, and Pan Pacific firms. J. Oper. Mgmt., 1998, 16, 159-176.

Netemeyer, R.G., Johnston, M.W. and Burton, S., Analysis of role conflict and role ambiguity in a structural equations framework. J. Appl. Psychol., 1990, 75, 148-57.

Olhager, J., Supply chain management: a just-in-time perspective. Prod. Planning Control, 2002, 13, 681-687.

Olavarrieta, S. and Ellinger, A.E., Resource-based theory and strategic logistics research. Int. J. Phys. Distribution Logistics Mgmt., 1997, 27, 559-587.

Palepu, K., Diversification strategy, profit performance and the entropy measure. Strategic Mgmt. J., 1985, 6, 239-256.

Penrose, E., The Theory of Growth of the Firm, 1959 (Wiley: New York).

Porter, M.E., How competitive forces shape strategy. McKinsey Quart., 1980, 2, 34-51.

Porter, M.E., Technology and competitive advantage. J. Bus. Strategy, 1985, 5, 60-79.

Prahalad, C.K. and Hamel, G., The core competence of the corporation. Har. Bus. Rev., 1990, 68, 79-91.

Ragatz, G.L., Handfield, R.B. and Petersen, K.J., Benefits associated with supplier integration into new product development under conditions of technology uncertainty. J. Bus. Res., 2002, 55, 389-400. 
Randall, T.R., Morgan, R.M. and Morton, A.R., Efficient versus responsive supply chain choice: an empirical examination of influential factors. J. Prod. Innovation Mgmt., 2003, 20, 430-443.

Reed, R. and DeFillippi, R.J., Causal ambiguity, barriers to imitation and sustainable competitive advantage. Acad. Mgmt. Rev., 1990, 15, 88-102.

Romano, P., Impact of supply chain sensitivity to quality certification on quality management practices and performances. Total Quality Mgmt., 2002, 13, 981-1001.

Roth, A.V. and Miller, J.G., Success factors in manufacturing. Busi. Horizons, 1992, July-August, 73-81.

Safizadeh, M.H., Ritzman, L.P. and Mallick, D., Revisiting alternative theoretical paradigms in manufacturing strategy. Prod. Oper. Mgmt., 2000, 9, 111-127.

Sakakibara, S., Flynn, B.B., Schroeder, R.G. and Morris, W.T., The impact of just-in-time manufacturing and its infrastructure on manufacturing performance. Mgmt. Sci., 1997, 43, 1246-1257.

Samson, D. and Terziovski, M., The relationship between total quality management practices and operational performance. J. Oper. Mgmt., 1999, 17, 393-412.

Shock, C.L., Ketchen, D.J., Hult, G.T. and Kacmar, K.M., An assessment of the use of structural equation modeling in strategic management research. Strategic Mgmt. J., 2004, 25, 397-404.

Sinkovics, R.R. and Roath, A.S., Strategic orientation, capabilities, and performance in manufacturer-3PL relationships. J. Bus. Logistics, 2004, 25, 43-64.

Steiger, J.H., Structural model evaluation and modification: an interval estimation approach. Multivariate Behavioral Res., 1990, 25, 173-180.

Tan, K.C., A structural equation model of new product design and development. Deci. Sci., 2001, 32, 195-226.

Tan, K.C., Supply chain management: practices, concerns, and performance issues. J. Supp. Chain Mgmt., 2002, 38, 42-53.

Tan, K.C., Handfield, R.B. and Krause, D.R., Enhancing the firm's performance through quality and supply base management: an empirical study. Int. J. Prod. Res., 1998, 36, 2813-2837.

Tan, K.C., Kannan, V.R., Jayaram, J. and Narasimhan, R., Acquisition of operations capability: a model and test across US and European firms. Int. J. Prod. Res., 2004, 42, 833-852.

Tatikonda, M.V. and Stock, G.N., Product technology transfer in the upstream supply chain. J. Prod. Innovation Mgmt., 2003, 20, 444-463.

Tully, S., Purchasing's new muscle. Fortune, 1995, 20, 76.

Vickery, S.K., Droge, C. and Markland, R.E., Production competence and business strategy: do they affect business performance? Deci. Sci., 1993, 24, 435-455.

Vickery, S.K., Jayaram, J., Droge, C. and Calantone, R., The effects of an integrative supply chain strategy on customer service and financial performance: an analysis of direct versus indirect relationships. J. Oper. Mgmt., 2003, 21, 523-539.

Ward, P.T., McCreery, J.K., Ritzman, L.P. and Sharma, D., Competitive priorities in operations management. Deci. Sci., 1998, 29, 1035-1046.

Wisner, J.D., A structural equation model of supply chain management strategies and firm performance. J. Busi. Logistics, 2003, 24, 1-26.

Yang, J.S. and Pan, C.H., Just-in-time purchasing: an integrated inventory model involving deterministic variable lead time and quality improvement investment. Int. J. Prod. Res., 2004, 42, 853-863.

Zirger, B.J. and Hartley, J.L., The effect of accelerated techniques on product development time. IEEE Trans. Engng. Mgmt., 1996, 43, 143-152.

Zsidisin, G.A., Ellram, L.A. and Ogden, J.A., The relationship between purchasing and supply management's perceived value and participation in strategic supplier cost management activities. J. Busi. Logistics, 2003, 24, 129-154. 